\title{
Shared Decision Making for COVID-19 Vaccine in Pregnancy/Lactation
}

Lily J. Lou, MD, FAAP

Dear All,

I hope you are all finding joy with those you love between all your hard-working hours as 2020 nears its end. How timely that the first COVID-19 vaccine is a gift to us in the holiday season.

The Advisory Committee on Immunization Practices (ACIP) met on Friday and Saturday (December $11^{\text {th }} \& 12^{\text {th }}$ ) to discuss and develop guidance on the Pfizer-BioNTech COVID-19 vaccine, the first COVID-19 vaccine to attain Emergency Use Authorization (EUA)-issued on December $10^{\text {th }}$.

Things continue to move rapidly, but here are a few key points about this first offering:

- $\quad$ ACIP voted to approve use in patients 16 years of age or older.

- This is an mRNA vaccine (see box for descriptions of types).

- $\quad$ This vaccine requires two doses, 21 days apart. Immunity is estimated to be $52 \%$ after the first dose and $95 \%$ after the second dose. There is no data supporting the effectiveness if the second dose is with a different COVID vaccine, so the same manufacturer should be used to complete the series.

- Prioritization of vaccine access is a hot topic of discussion. Health care workers will receive the vaccine first, as will residents of long-term care facilities. Other 'essential' workers will follow.

- The issue of pregnant and lactating mothers is not settled

- Acetaminophen is recommended after vaccination in pregnant women to minimize risks to the fetus from significant fever. (This is different from the typical recommendation to avoid routine Tylenol with childhood immunization unless symptoms develop, as it may suppress the immune response and thus the effectiveness of the vaccine.)

For neonatologists, the last point is very important. Pregnant women are recognized to be at increased risk of death or serious disease with COVID-19, but they have not been included in vaccine trials. Some women have become pregnant during their trial participation, but this data is not yet released. The DART (developmental and reproductive toxicity) studies are slated to be released in late December. Pfizer stated that preliminary data showed no evidence of toxicity. Based on what we know about other coronavirus vaccine studies, "the overall complete consensus was that we don't see biological plausibility at this time for placental transfer of the mRNA and that we see that direct fetal exposure or the possibility of fetal inflammatory response is extremely unlikely," said Eckert, professor of obstetrics and gynecology at the UW-Seattle, and the ACOG representative to ACIP. "Clearly, we are waiting on the data."
Currently, there are three main types of COVID-19 vaccines under development. Here is a description from the CDC. A fourth type-inactivated virus-is not one of the front-runners at this point.

- mRNA vaccines contain material from the virus that causes COVID-19 that gives our cells instructions for how to make a harmless protein that is unique to the virus. After our cells make copies of the protein, they destroy the genetic material from the vaccine. Our bodies recognize that the protein should not be there and build T-lymphocytes and B-lymphocytes that will remember how to fight the virus that causes COVID-19 if we are infected in the future.

- Protein subunit vaccines include harmless pieces (proteins) of the virus that cause COVID-19 instead of the entire germ. Once vaccinated, our immune system recognizes that the proteins don't belong in the body and begins making Tlymphocytes and antibodies. If we are ever infected in the future, memory cells will recognize and fight the virus.

- Vector vaccines contain a weakened version of a live virus-a different virus than the one that causes COVID-19-that has genetic material from the virus that causes COVID-19 inserted in it (this is called a viral vector). Once the viral vector is inside our cells, the genetic material gives cells instructions to make a protein that is unique to the virus that causes COVID-19. Using these instructions, our cells make copies of the protein. This prompts our bodies to build T-lymphocytes and B-lymphocytes that will remember how to fight that virus if we are infected in the future.

Regarding breastfeeding mothers, a recent article (https:// pubmed.ncbi.nlm.nih.gov/32822495/) showed a lack of transmission of the SARS-CoV-2 virus in breastmilk; however, other studies have demonstrated the presence of $\lg A$ against the virus. There is no data available yet regarding the transmission of vaccine components.

"Pregnant women are recognized to be at increased risk of death or serious disease with COVID-19, but they have not been included in vaccine trials. Some women have become pregnant during their trial participation, but this data is not yet released. The DART (developmental and reproductive toxicity) studies are slated to be released in late December." 


\section{"The strong recommendation is} for pregnant and nursing women to undertake shared decision-making with their providers, based on local community risk and the individual's risk factors."

The strong recommendation is for pregnant and nursing women to undertake shared decision-making with their providers, based on local community risk and the individual's risk factors. This may limit the liability of the manufacturer and is understandable with the paucity of data. Note that in the UK, the recommendation is for women who are pregnant (from 3 months prior to pregnancy to after delivery) to refrain from vaccination (https://www.gov.uk/ government/publications/covid-19-vaccination-women-of-childbearing-age-currently-pregnant-planning-a-pregnancy-or-breastfeeding/covid-19-vaccination-a-guide-for-women-of-childbearingage-pregnant-planning-a-pregnancy-or-breastfeeding).

For any provider engaging in shared decision-making with such patients (pregnant or lactating women, as well as immunocompromised patients, and perhaps teenagers), it is essential that good documentation is done, with a clear notation of the risks and benefits discussed and the rationale for giving or withholding the vaccine.

Questions about this important perinatal population notwithstanding, I am excited about the prospect of a COVID-19 vaccine. With proper recognition of the rapidity of its development, built on the shoulders of decades of coronavirus research, it will be important to keep up with the data as it evolves. This will be especially important as different types of vaccine become available, and as study populations are expanded to include broader age ranges and special groups.

Here are some references with more details on the recent vaccine guidance:

1. https://services.aap.org/en/pages/2019-novel-coronaviruscovid-19-infections/covid-19-vaccine-frequently-askedquestions/

2. https://www.acog.org/-/media/project/acog/acogorg/files/ advocacy/letters/2020/12/letter-urging-acip-to-include-pregnant-and-lactating-individuals-in-an-eua-for-a-covid-19-vaccine.pdf

3. https://s3.amazonaws.com/cdn.smfm.org/media/2591/ SMFM Vaccine Statement 12-1-20 (final).pdf

4. $\quad$ https://www.medscape.com/viewarticle/942558
5. https://www.medscape.com/viewarticle/942557

6. https://www.fda.gov/media/144413/download?utm medium=email\&utm source $=$ govdelivery

7. https://www.acog.org/en/clinical/clinical-quidance/practiceadvisory/articles/2020/12/vaccinating-pregnant-and-lactating-patients-against-covid-19

Thank you to all the vaccine scientists who labored to bring this to fruition, to all of the public health leaders and workers who will get the vaccine from the manufacturers to the people who need protection, and to all of the front line clinicians who continue to care for your patients and their families. With that, I will close and wish you a good week and a safe holiday season.

Warmly,

Lily

Disclosure: There are no reported conflicts.

NT

\begin{tabular}{l} 
Corresponding Author \\
Lily J. Lou, MD, FAAP \\
Chair, AAP Section on Neonatal-Perinatal Medicine \\
Co-chair, SONPM Advocacy Committee \\
Immediate Past Chair, AAP-Alaska Chapter \\
Professor of Clinical Pediatrics \\
Director of Government Relations \\
University of Illinois at Chicago \\
Division of Neonatology, MC 856 \\
Department of Pediatrics \\
1253 CSB \\
840 S. Wood St. \\
Chicago, IL 60612 \\
lilylou@uic.edu \\
(312) 996-4185 office \\
(907) 632-4378 cell \\
\hline
\end{tabular}

NEONATOLOGY TODAY is interested in publishing manuscripts from Neonatologists, Fellows, NNPs and those involved in caring for neonates on case studies, research results, hospital news, meeting announcements, and other pertinent topics.

Please submit your manuscript to: LomaLindaPublishingCompany@gmail.com 